\title{
Hypoxia-inducible factor 1 mediates hypoxia-enhanced synthesis of progesterone during luteinization of granulosa cells
}

\author{
FADHILLAH ${ }^{1)}$, Shin YOSHIOKA ${ }^{1)}$, Ryo NISHIMURA ${ }^{2)}$, Yuki YAMAMOTO ${ }^{1)}$, Koji KIMURA ${ }^{1)}$ and \\ Kiyoshi OKUDA ${ }^{1,3)}$ \\ 1) Laboratory of Reproductive Physiology, Graduate School of Environmental and Life Sciences, Okayama University, \\ Okayama 700-8530, Japan \\ 2) Laboratory of Theriogenology, Joint Department of Veterinary Medicine, Faculty of Agriculture, Tottori University, \\ Tottori 680-8550, Japan \\ ${ }^{3)}$ Obihiro University of Agriculture and Veterinary Medicine, Inada Nishi 2-11, Obihiro 080-8555, Japan
}

\begin{abstract}
Hypoxia has been suggested to enhance progesterone (P4) synthesis in luteinizing granulosa cells (GCs), but the mechanism is unclear. The present study was designed to test the hypothesis that the hypoxia-induced increase in P4 synthesis during luteinization in bovine GCs is mediated by hypoxia-inducible factor 1 (HIF-1). GCs obtained from small antral follicles were cultured with $2 \mu \mathrm{g} / \mathrm{ml}$ insulin in combination with $10 \mu \mathrm{M}$ forskolin for $24 \mathrm{~h}$ as a model of luteinizing GCs. To examine the influence of HIF-1 on P4 synthesis, we determined the effect of changes in protein expression of the $\alpha$-subunit of HIF-1 (HIF1A) on P4 production and on the expression levels of StAR, P450scc, and $3 \beta-\mathrm{HSD}_{\mathrm{S}} \mathrm{CoCl} \mathrm{L}_{2}(100 \mu \mathrm{M})$, a hypoxia-mimicking chemical, increased HIF-1 $\alpha$ protein expression in luteinizing GCs. After the upregulation of HIF-1 $\alpha$, we observed an increase in $\mathrm{P} 4$ production and in the gene and protein expression levels of StAR in $\mathrm{CoCl}_{2}$-treated luteinizing GCs. In contrast, $\mathrm{CoCl}_{2}$ did not affect the expression of either P450scc or 3 $\beta$-HSD. Echinomycin, a small-molecule inhibitor of HIF-1's DNA-binding activity, attenuated the effects of $\mathrm{CoCl}_{2}$ and of low oxygen tension $\left(10 \% \mathrm{O}_{2}\right)$ on $\mathrm{P} 4$ production and StAR expression in luteinizing GCs. Overall, these findings suggest that HIF-1 is one of the factors that upregulate P4 in GCs during luteinization.
\end{abstract}

Key words: Corpus luteum, Granulosa cell, Ovary, Progesterone

(J. Reprod. Dev. 63: 75-85, 2017)

D uring follicular growth, blood vessels that develop during follicular maturation in the theca cell layer do not penetrate the basement membrane [1]. The granulosa cell (GC) layer remains avascular until the breakdown of the basement membrane; thus, GCs are believed to develop under low oxygen $\left(\mathrm{O}_{2}\right)$ tension or hypoxic conditions, as compared to atmospheric $\mathrm{O}_{2}$ tension [2-4]. Immediately after ovulation, the ruptured follicle is also thought to be under low oxygen tension due to bleeding and immature vascularization [5].

Cellular responses to hypoxic conditions are mediated by hypoxiainducible factor 1 (HIF-1), an oxygen-regulated transcriptional activator [6]. HIF-1 is composed of two subunits: the oxygen-sensitive HIF- $1 \alpha$ subunit and the constitutively expressed HIF-1 $\beta$ subunit $[6$, 7]. Under hypoxic conditions, the HIF-1 $\alpha$ protein is stabilized and translocated from the cytoplasm to the nucleus, where it dimerizes with HIF-1 $\beta$. This heterodimer then binds to a hypoxia response element (HRE) in target gene promoters and activates transcription of HIF-controlled genes involved in many physiological functions $[6,7]$. There is increasing evidence that HIFs participate in ovulation

Received: April 30, 2016

Accepted: October 17, 2016

Published online in J-STAGE: November 11, 2016

C)2017 by the Society for Reproduction and Development

Correspondence: K Okuda (e-mail: kokuda@okayama-u.ac.jp)

This is an open-access article distributed under the terms of the Creative Commons Attribution Non-Commercial No Derivatives (by-nc-nd) License $<$ http://creativecommons.org/licenses/by-nc-nd/4.0/>. and follicular differentiation. HIF-1 $\alpha$, induced by various stimuli, is suggested to serve as a key mediator of endothelin 2 expression, which performs a crucial function in ovulation in mammals [8]. In mice, HIFs control follicular rupture by regulating the expression of a specific subset of progesterone receptor (PGR)'s target genes, whereas blocking of HIF activity impairs ovulation [2]. Human chorionic gonadotropin (hCG) in synergy with hypoxic conditions has been demonstrated to up-regulate HIF- $1 \alpha$ activity within luteinizing GCs both in vivo and in vitro; these findings suggest the fundamental roles for HIFs in follicle differentiation [9].

The protein level of HIF- $1 \alpha$ increases in response to several stimuli, including hypoxia, proteasomal inhibitors, transition metals $\mathrm{CO}^{2+}$, $\mathrm{Mn}^{2+}$, and $\mathrm{Ni}^{2+}$ ), iron chelators [hydrophilic desferrioxamine (DFO) and lipophilic 2,2'-dipiridyl (DP)] and other stressors [10-12]. Iron chelators and transition metals suppress the interaction between iron-mediated hydroxylation of HIF- $1 \alpha$ and pVHL binding and inhibit hydroxylation of a key proline residue within the ODD domain of HIF- $1 \alpha$, thus resulting in accumulation of the HIF-1 $\alpha$ protein [11]. Treatment with cobalt chloride $\left(\mathrm{CoCl}_{2}\right)$ was found to mimic HIF-1 activation through inhibition of HIF-1 $\alpha$ degradation. In latter process, HIF-1activation strongly induces vascular endothelial growth factor (VEGF), which represents the most important mechanism for hypoxiainduced angiogenesis in GCs of several species [12-17]. On the other hand, HIF-1's DNA-binding activity in the promoter region of target genes can be inhibited by echinomycin, a cyclic peptide that was originally discovered as a sequence-specific DNA-binding agent [18]. 
During the differentiation of GCs and theca cells into luteal cells, called the luteinization process, the main steroid product of ovaries (estrogen synthesized by follicles) is replaced by progesterone (P4) produced by the corpus luteum [19]. These changes are mediated by differentiation-dependent modification of the steroidogenic pathway. The key proteins and enzymes in $\mathrm{P} 4$ synthesis include steroidogenic acute regulatory protein (StAR; STAR), which transports cholesterol from the outer to inner mitochondrial membrane; cytochrome P450 side chain cleavage enzyme (P450scc; CYP11A1), which converts cholesterol into pregnenolone; and $3 \beta$-hydroxysteroid dehydrogenase (3ß-HSD; HSD3B), which converts pregnenolone into P4 [20-24]. The rupture and collapse of a follicle at ovulation and the invasion by some elements, including theca cells and blood vessels, also commonly take place during luteinization [25].

Luteinization is thought to occur in a hypoxic environment. We previously suggested that hypoxia promotes $\mathrm{P} 4$ synthesis in our model of bovine luteinizing GCs [26]. Nevertheless, whether HIF-1 plays a role in hypoxia-driven enhancement of $\mathrm{P} 4$ synthesis during luteinization is not clear.

In the present study, we hypothesized that the hypoxia-induced increase in P4 synthesis during luteinization in bovine GCs is mediated by HIF-1. To test this hypothesis, we evaluated the effect of changes in the protein level of the $\alpha$-subunit of HIF-1 by means of a hypoxia-mimetic compound $\left(\mathrm{CoCl}_{2}\right)$ and by means of low-oxygen-tension culture with or without echinomycin in bovine cultured luteinizing and non-luteinizing GCs. We then quantified the $\mathrm{P} 4$ production as well as mRNA and protein expression of StAR, P450scc, and 3 $\beta-H S D$ in these cells.

\section{Materials and Methods}

\section{GC isolation and culture}

Bovine ovaries were obtained from a local slaughterhouse and were transported to the laboratory in ice-cold sterile physiological saline. The ovaries with healthy follicles were washed several times in sterile saline containing $100 \mathrm{IU} / \mathrm{ml}$ penicillin (Meiji Seika Pharma, Tokyo, Japan; 611400D3051) and $100 \mu \mathrm{g} / \mathrm{ml}$ streptomycin (Meiji Seika Pharma; 6161400D1034) as described previously [26]. GCs in follicular fluid were aspirated aseptically from healthy small follicles ( $\leq 6 \mathrm{~mm}$ in diameter) using a $2.5-\mathrm{ml}$ disposable syringe and a 24-gauge needle, were pooled, then transferred to a plastic Petri dish filled with Dulbecco's Modified Eagle's Medium (DMEM) and Ham's F-12 medium (1:1 [v/v]; Invitrogen, Carlsbad, CA, USA; 12400-024) containing 10\% of calf serum (Invitrogen; 16170078), $20 \mu \mathrm{g} / \mathrm{ml}$ gentamicin (Sigma-Aldrich, St. Louis, MO, USA; G1397), $2 \mu \mathrm{g} / \mathrm{ml}$ amphotericin B (Sigma-Aldrich; A9528), and 50 IU heparin sodium salt (Nacalai Tesque, Kyoto, Japan; 17513-41). After removal of cumulus-oocyte complexes with a fine glass pipet under a dissecting microscope, GCs in follicular fluid were centrifuged $\left(800 \times g, 5 \mathrm{~min}\right.$ at $\left.4^{\circ} \mathrm{C}\right)$, then resuspended in Tris- $\mathrm{HCl}$ buffer ( $25 \mathrm{mM}, \mathrm{pH} 7.4)$ to rupture the blood cells after discarding the supernatant. The cell suspensions were centrifuged again and resuspended in DMEM (Sigma-Aldrich; D1152) supplemented with $100 \mathrm{IU} / \mathrm{ml}$ penicillin, $100 \mu \mathrm{g} / \mathrm{ml}$ streptomycin, and $0.1 \%$ of bovine serum albumin (BSA; Roche Diagnostics, Manheim, Germany; 10735086001) after the supernatant was discarded. This washing step was performed twice. The cell suspensions were then centrifuged, filtered through metal meshes $(100 \mu \mathrm{m} \times 2,80 \mu \mathrm{m} \times 2)$ to avoid cell aggregation, and were resuspended in a suitable volume of the culture medium (DMEM and Ham's F-12 containing 10\% of calf serum and $20 \mu \mathrm{g} / \mathrm{ml}$ gentamicin). The viability of GCs was assessed by a trypan blue dye exclusion assay.

The dispersed GCs were seeded at $0.5 \times 10^{5}$ viable cells per 1 $\mathrm{ml}$ in the culture medium in $75-\mathrm{cm}^{2}$ culture flasks $(20 \mathrm{ml} / \mathrm{flask}$; Greiner Bio-One, Frickenhausen, Germany; 658175) and cultured in a humidified atmosphere containing $5 \% \mathrm{CO}_{2}$ at $37.5^{\circ} \mathrm{C}$ in a $\mathrm{N}_{2}-\mathrm{O}_{2}-\mathrm{CO}_{2}$-regulated incubator (ESPEC, Osaka, Japan; BNP-110) for 3-4 days. When the cultured cells reached $80-90 \%$ confluence, cell passaging was conducted using $0.1 \%$ bovine trypsin (SigmaAldrich; T92012) and sterile phosphate-buffered saline (PBS; Nissui Pharmaceutical, Tokyo, Japan; 05913). The GCs were seeded at the concentration of $2.0 \times 10^{5}$ viable cells per $1 \mathrm{ml}$ in 48 -well cluster dishes $(0.5 \mathrm{ml} /$ well; Greiner Bio-One; 662160$)$ for quantification of $\mathrm{P} 4$ production, in 96 -well cluster dishes $(0.1 \mathrm{ml} /$ well; Iwaki, Chiba, Japan; 3860-096) for the cell viability assay, in 24-well cluster dishes ( $1.0 \mathrm{ml} /$ well; Greiner Bio-One; 677180$)$ for determination of gene expression, and in $75 \mathrm{~cm}^{2}$ culture flasks (20 ml/flask; Greiner Bio-One; 658175) for analysis of protein expression.

\section{Preparation of luteinizing and non-luteinizing GCs and hypoxic culture conditions}

To prepare luteinizing and non-luteinizing GCs, the culture medium was replaced with a fresh medium containing $0.1 \%$ of BSA, $5 \mathrm{ng} /$ $\mathrm{ml}$ sodium selenite (Sigma-Aldrich; S5261), $5 \mu \mathrm{g} / \mathrm{ml}$ transferrin (Sigma-Aldrich; T4132), and $0.5 \mathrm{mM}$ ascorbic acid (Wako-Pure Chemical Industries Osaka, Japan; 031-12061), and the cells were then incubated in a normal culture atmosphere $\left(20 \% \mathrm{O}_{2}, 5 \% \mathrm{CO}_{2}\right.$, and $\left.75 \% \mathrm{~N}_{2}\right)$ with or without insulin $(2 \mu \mathrm{g} / \mathrm{ml}$; Sigma-Aldrich; I4011) in the medium in combination with forskolin $(10 \mu \mathrm{M}$; Research Biochemicals International, Natick, MA, USA; 70-0501-05) for $24 \mathrm{~h}$. Insulin and insulin-like growth factor I (IGF-I) are known to stimulate proliferation of (and P4 production in) GCs [27-31]. In addition, forskolin increases intracellular cyclic AMP concentration via activation of adenylate cyclase [32]. Insulin in combination with forskolin mimics the effects of luteinizing hormone ( $\mathrm{LH}$ ) and activates adenylate cyclase via upregulation of $\mathrm{P} 4$ [33]. The concentration of insulin and forskolin was selected according to other reports [26, 34].

\section{Experiment 1: Effects of $\mathrm{CoCl}_{2}$ on P4 production and cell viability}

To determine the effects of hypoxia, a hypoxia-mimicking agent $\left(\mathrm{CoCl}_{2}\right.$; Sigma-Aldrich; C8661) was used. The luteinizing and non-luteinizing GCs were cultured in the presence or absence of $\mathrm{CoCl}_{2}(100$ or $250 \mu \mathrm{M})$ for 2,6 , or $24 \mathrm{~h}$. The conditioned media and the cultured cells were then collected to quantify $\mathrm{P} 4$ production by an enzyme immunoassay (EIA) and a spectrophotometric method. The cell viability after $24 \mathrm{~h}$ culture was also determined by Dojindo Cell Counting Kit including WST-1 (Dojindo, Kumamoto, Japan; 345-06463). 
Experiment 2: Effects of $\mathrm{CoCl}_{2}$ on $m R N A$ and protein expression levels of StAR, P450scc, and $3 \beta-H S D$

To measure the effect of $\mathrm{CoCl}_{2}$ on $\mathrm{P} 4$ synthesis, mRNA and protein expression levels of StAR, P450scc, and 3 $\beta$-HSD were also evaluated. The luteinizing and non-luteinizing GCs were cultured in the presence or absence of $\mathrm{CoCl}_{2}(100$ or $250 \mu \mathrm{M})$ for 2 or $6 \mathrm{~h}$. The cells were then collected for real-time PCR and western blotting.

\section{Experiment 3: The effect of $\mathrm{CoCl}_{2}$ on HIF-1 $\alpha$ protein expression}

Because HIF- $1 \alpha$ expression is known to be strongly regulated by hypoxic conditions, we determined the effect of $\mathrm{CoCl}_{2}$ on HIF-1 $\alpha$ protein expression. The luteinizing and non-luteinizing GCs were cultured in the presence or absence of $\mathrm{CoCl}_{2}(100$ or $250 \mu \mathrm{M})$ for 2,6 , or $24 \mathrm{~h}$. The cultured cells were then washed with PBS and harvested for western blotting.

\section{Experiment 4: The effect of echinomycin on $\mathrm{CoCl}_{2}$-enhanced P4 synthesis}

To demonstrate the involvement of HIF-1 $\alpha$ in $\mathrm{CoCl}_{2}$-enhanced P4 synthesis, echinomycin (Sigma-Aldrich; SML0477), a smallmolecule inhibitor of HIF-1 activity, was used. The luteinizing and non-luteinizing GCs were exposed to $\mathrm{CoCl}_{2}(100 \mu \mathrm{M})$ in the presence or absence of echinomycin for 2 or $6 \mathrm{~h}$. P4 production and mRNA and protein expression levels of STAR, P450scc, and $3 \beta-H S D$ were then quantified.

\section{Experiment 5: The effect of echinomycin on 10\% $\mathrm{O}_{2}$-enhanced P4 synthesis}

In our previous study, we found that $10 \% \mathrm{O}_{2}$ increases $\mathrm{P} 4$ synthesis [26]. To determine the role of HIF-1 in $10 \% \mathrm{O}_{2}$-enhanced P4 synthesis, echinomycin - a small molecule inhibitor of HIF-1 activity [18] — was added to the culture medium of luteinizing and non-luteinizing GCs incubated at $10 \% \mathrm{O}_{2}$ for $24 \mathrm{~h}$. P4 production and the mRNA and protein expression levels of STAR, P450scc, and $3 \beta$-HSD were then measured.

\section{Quantification of P4 production}

To measure $\mathrm{P} 4$ production, EIA and DNA assay were performed. The conditioned media were collected and stored at $-30^{\circ} \mathrm{C}$ until analysis of $\mathrm{P} 4$ concentration. This concentration was determined by EIA as described previously [35]. The standard curve had a range from 0.391 to $100 \mathrm{ng} / \mathrm{ml}$. To fit the range of concentrations of the standards, the culture media were diluted 1:10. The cultured cells were also stored at $-30^{\circ} \mathrm{C}$ until the DNA content was measured by spectrophotometry as described previously [36] and was used to normalize the P4 concentrations. Four experiments were conducted, and each treatment was tested in triplicate wells in each experiment. Neither $\mathrm{CoCl}_{2}$ nor $10 \% \mathrm{O}_{2}$ altered the cell number (data not shown).

\section{RNA isolation, cDNA synthesis, and real-time PCR}

Total RNA was extracted to determine mRNA expression of STAR, CYP11A1, and HSD3B. For this purpose, we used TRIsure (Bioline, London, UK; BIO-38033). The extracted RNA from each sample was quantified using a NanoDrop Lite Spectrophotometer (Thermo Fisher Scientific, Waltham, MA, USA). The total RNA was reverse-transcribed on a ThermoScript RT-PCR system (Invitrogen; 11146-016).

STAR, CYP11A1, and HSD3B mRNA expression levels were measured by real-time PCR using the MyiQ (Bio-Rad, Tokyo, Japan) and the iQ SYBR Green supermix (Bio-Rad; 170-8880) starting with $1 \mathrm{ng}$ of reverse-transcribed total RNA as described previously [37]. Standard curves of sample cDNA were generated using serial dilutions $(1: 2$ to 1:1,000). Expression of the 18S ribosomal RNA gene (18SrRNA) served as an internal control. In a preliminary experiment, 18SrRNA was confirmed to not be influenced by luteinization and hypoxia (data not shown). Twenty-base pair primers with 50-60\% GC content were synthesized for PCR (Table 1).

The PCR conditions were as follows: $95^{\circ} \mathrm{C}$ for $30 \mathrm{sec}$, followed by $45 \mathrm{cycles}$ of $94^{\circ} \mathrm{C}$ for $6 \mathrm{sec}, 60^{\circ} \mathrm{C}$ for $30 \mathrm{sec}$, and $65^{\circ} \mathrm{C}$ for $6 \mathrm{sec}$. The use of the QuantiTect SYBR Green PCR system at elevated temperatures resulted in reliable and sensitive quantification of the PCR products, with high linearity. The melting curve analysis was used to confirm that only the target amplicon was amplified.

\section{Western blotting}

The cells were washed with ice-cold PBS, scraped from the culture flask in $1 \mathrm{ml}$ of ice-cold homogenization buffer $(25 \mathrm{mM}$ Tris- $\mathrm{HCl}$ pH 7.4, $300 \mathrm{mM}$ sucrose, $2 \mathrm{mM}$ EDTA, and Complete [protease inhibitor cocktail; Roche Diagnostics; 11697498001]). The cell suspension was centrifuged at $19,000 \times g$ for $30 \mathrm{~min}$, the supernatant was discarded, and the pellet was lysed in $100 \mu$ l of lysis buffer $(20$ $\mathrm{mM}$ Tris- $\mathrm{HCl} \mathrm{pH} 7.4,150 \mathrm{mM} \mathrm{NaCl}, 1 \%$ of Triton X-100, $10 \%$ of glycerol [Sigma; G7757], and Complete). The protein samples were then stored at $-80^{\circ} \mathrm{C}$ until protein expression of HIF- $1 \alpha$, StAR, P450sec, and 3 $\beta-H S D$ was analyzed by western blotting.

Table 1. Primers used in real-time PCR

\begin{tabular}{|c|c|c|c|c|}
\hline Gene & Primer & Sequence $\left(5^{\prime}-3^{\prime}\right)$ & Accession no. & Product (bp) \\
\hline \multirow[t]{2}{*}{ STAR } & Forward & CCCATGGAGAGGCTTTATGA & Y17259 & 115 \\
\hline & Reverse & TGATGACCGTGTCTTTTCCA & & \\
\hline \multirow[t]{2}{*}{ CYP11A1 } & Forward & CTGGCATCTCCACAAAGACC & $\mathrm{J} 05245$ & 131 \\
\hline & Reverse & GTTCTCGATGTGGCGAAAGT & & \\
\hline \multirow[t]{2}{*}{$H S D 3 B$} & Forward & CCAAGCAGAAAACCAAGGAG & X17614 & 109 \\
\hline & Reverse & ATGTCCACGTTCCCATCATT & & \\
\hline \multirow[t]{2}{*}{$18 S r R N A$} & Forward & TCGCGGAAGGATTTAAAGTG & AY779625 & 141 \\
\hline & Reverse & AAACGGCTACCACATCCAAG & & \\
\hline
\end{tabular}


The protein concentration was determined by the method described elsewhere [38], using BSA as a standard. The protein samples were solubilized in SDS gel-loading buffer (50 mM Tris- $\mathrm{HCl} \mathrm{pH}$ 6.8, 2\% of SDS [Nacalai Tesque; 31607-94], 10\% of glycerol, and 1\% of $\beta$-mercaptoethanol [Wako Pure Chemical Industries; 137-06862]) and heated at $95^{\circ} \mathrm{C}$ for $10 \mathrm{~min}$. Next, the samples $(50 \mu \mathrm{g}$ protein) were subjected to SDS-PAGE in a 7.5\% gel with pre-stained molecular weight markers (Bio-Rad; 161-0374) for $1 \mathrm{~h}$ at $200 \mathrm{~V}$.

The separated proteins were electrophoretically transblotted to a PVDF membrane (GE Healthcare, Limited, Buckinghamshire, UK; RPN1416LFP) for $1 \mathrm{~h}$ at $25 \mathrm{~V}$ in transfer buffer (25 mM Tris- $\mathrm{HCl}$, $192 \mathrm{mM}$ glycine, and $20 \%$ of methanol). The membrane was washed in TBS-T $(0.1 \%$ of Tween 20 in TBS [25 mM Tris-HCl, $137 \mathrm{mM}$ $\mathrm{NaCl}, \mathrm{pH}$ 7.5]) for $10 \mathrm{~min}$ and was incubated in PVDF blocking buffer (Toyobo, Osaka, Japan; NYBR01) for $1 \mathrm{~h}$ at room temperature. The membranes were then incubated separately with a primary antibody in an immunoreaction enhancer solution (Toyobo; NKB-101) specific to each protein: an anti-HIF-1 $\alpha$ antibody (Sigma-Aldrich; SAB2104366; 1:500), anti-StAR antibody (Abcam; ab96637; 1:3,000); anti-P450scc antibody (Abcam; ab75497; 1:1,000), anti-3 $\beta$-HSD antibody (Abcam; ab75710; $1: 3,000$ ), and an anti- $\beta$-actin antibody (ACTB; SigmaAldrich; A2228; $1: 8,000)$ overnight at $4^{\circ} \mathrm{C}$. The membranes were washed three times for $5 \mathrm{~min}$ in TBS-T at room temperature, incubated with a secondary antibody in the immunoreaction enhancer solution (for HIF-1 $\alpha$, StAR, and P450scc [1:5,000 dilution]: an anti-rabbit IgG horseradish peroxidase [HRP]-conjugated whole antibody produced in donkey; Amersham Biosciences, Piscataway, NJ; NA934; 33-HSD and ACTB [1:40,000]: an anti-mouse IgG HRP-conjugated whole antibody produced in sheep; Amersham Biosciences; NA931) for $1 \mathrm{~h}$ and were washed three times in TBS-T 5 min each at room temperature. The signals were detected by means of the ECL Western Blotting Detection System (Amersham Biosciences; RPN2109). The intensity of the immunological reaction (HIF-1 $\alpha$, StAR, P450scc, $3 \beta$-HSD, and ACTB) in the cells was estimated by measuring optical density of a defined area by computerized densitometry in the NIH Image software (National Institutes of Health, Bethesda, MD, USA).

\section{The WST-1 assay}

WST-1, a version of MTT (3-[4,5-dimethyl-2 thiazolyl]-2,5diphenyl-2 H-tetrazolium bromide), is a yellow tetrazolium salt that is reduced to formazan by viable cells containing active mitochondria. The culture medium was replaced with $100 \mu \mathrm{l}$ of the D/F medium with BSA without phenol red, and a $10-\mu 1$ aliquot of the assay reagent (0.3\% WST-1, $0.2 \mathrm{mM} 1$-methoxy phenazine methosulfate in PBS, $\mathrm{pH}$ 7.4) was added to each well. The cells were then incubated for $4 \mathrm{~h}$ at $38^{\circ} \mathrm{C}$. The absorbance was read at $450 \mathrm{~nm}$ using a microplate reader (Model 450; Bio-Rad Laboratories). The measured absorbance directly correlates with the number of viable cells [39]. In this assay, data were expressed as a percentage of the appropriate control values.

\section{Statistical analyses}

All data are shown as mean $\pm \mathrm{SEM}$. The statistical analyses were performed in the GraphPad Prism 4 software. Statistical significance of differences in all experiments was assessed by one-way analysis of variance (ANOVA) followed by Fisher's protected least-significant difference procedure as a multiple-comparison test for each group: the group of non-luteinizing GCs and the group of luteinizing GCs. Differences with $\mathrm{P}<0.05$ were considered statistically significant.

\section{Results}

P4 production by luteinizing and non-luteinizing GCs

Insulin increased $\mathrm{P} 4$ production by GCs cultured for $24 \mathrm{~h}$ under $20 \% \mathrm{O}_{2}$ (Fig. 1A; $\mathrm{P}<0.05$ ). GCs cultured with insulin in combination with forskolin produced more $\mathrm{P} 4$. According to these results, the treated and untreated GCs were used as a model of luteinizing and non-luteinizing GCs in further experiments.

\section{Effects of $\mathrm{CoCl}_{2}$ on P4 production and cell viability}

To characterize the effects of hypoxia and HIF-1 $\alpha$, we cultured luteinizing and non-luteinizing GCs with 100 or $250 \mu \mathrm{M} \mathrm{CoCl}_{2}$ for 2, 6, or $24 \mathrm{~h}$. After 2 and $6 \mathrm{~h}$ of culture, 100 and $250 \mu \mathrm{M} \mathrm{CoCl}_{2}$ increased $\mathrm{P} 4$ production by luteinizing GCs, but these treatments did not have any effect on $\mathrm{P} 4$ production by non-luteinizing GCs (Fig. 1B and 1C). On the other hand, after $24 \mathrm{~h}$ of culture, 100 and $250 \mu \mathrm{M} \mathrm{CoCl}_{2}$ tended to decrease $\mathrm{P} 4$ production by luteinizing $\mathrm{GCs}$ (Fig. 1D). $\mathrm{CoCl}_{2}$ did not affect cell viability within $24 \mathrm{~h}$ after $\mathrm{CoCl}_{2}$ addition, meaning that $\mathrm{CoCl}_{2}$ under these conditions did not cause cell toxicity in this study (Fig. 1E).

\section{Effects of $\mathrm{CoCl}_{2}$ on $m R N A$ and protein expression levels of} StAR, P450scC, and $3 \beta-H S D$

To determine the effects of hypoxia and HIF-1 on P4 synthesis, we also analyzed the expression of key steroidogenic factors involved in P4 synthesis: StAR, P450scc, and 3 $\beta$-HSD. The real-time PCR analysis showed that $100 \mu \mathrm{M} \mathrm{CoCl}_{2}$ after $6 \mathrm{~h}$ significantly increased STAR mRNA expression in luteinizing GCs (Fig. 2A; $\mathrm{P}<0.05)$ but did not affect $C Y P 11 A 1$ and HSD3B mRNA expression levels (data not shown).

Western blotting analyses revealed that $100 \mu \mathrm{M} \mathrm{CoCl}_{2}$ after 2 and $6 \mathrm{~h}$ significantly increased StAR protein expression in luteinizing GCs (Fig. 2B; P < 0.05) but did not affect CYP11A1 and HSD3B protein expression (Fig. 2C and 2D).

\section{The effect of $\mathrm{CoCl}_{2}$ on HIF-1 $\alpha$ protein expression}

After 2 and $6 \mathrm{~h}$ of culture in the presence of $100 \mu \mathrm{M} \mathrm{CoCl}_{2}$, we observed the highest expression of the HIF- $1 \alpha$ protein concomitant with an increase in StAR protein expression (Fig. 3). Although the expression of HIF-1 $\alpha$ was detectable, there was no significant difference between the presence and the absence of $100 \mu \mathrm{M} \mathrm{CoCl}_{2}$ in culture. Based on these results, we chose $100 \mu \mathrm{M} \mathrm{CoCl}_{2}$ for 2 and 6 $\mathrm{h}$ as the conditions mimicking hypoxia in all subsequent experiments.

\section{The effect of echinomycin on $\mathrm{CoCl}_{2}$-enhanced $\mathrm{P} 4$ synthesis}

$0.5 \mathrm{nM}$ echinomycin inhibited $\mathrm{P} 4$ production (Fig. 4A; $\mathrm{P}<0.05$ ) and the expression of STAR mRNA (Fig. 4B; P < 0.05) and protein (Fig. 4C and 4D; $\mathrm{P}<0.05$ ) under hypoxic conditions induced by $\mathrm{CoCl}_{2}$ (incubation for 2 or $6 \mathrm{~h}$ ) in luteinizing GCs.

The effect of echinomycin on $10 \% \mathrm{O}_{2}$-enhanced $\mathrm{P} 4$ synthesis

We also evaluated the involvement of HIF-1 in $10 \% \mathrm{O}_{2}$-enhanced P4 synthesis by means of echinomycin. In agreement with our 
A
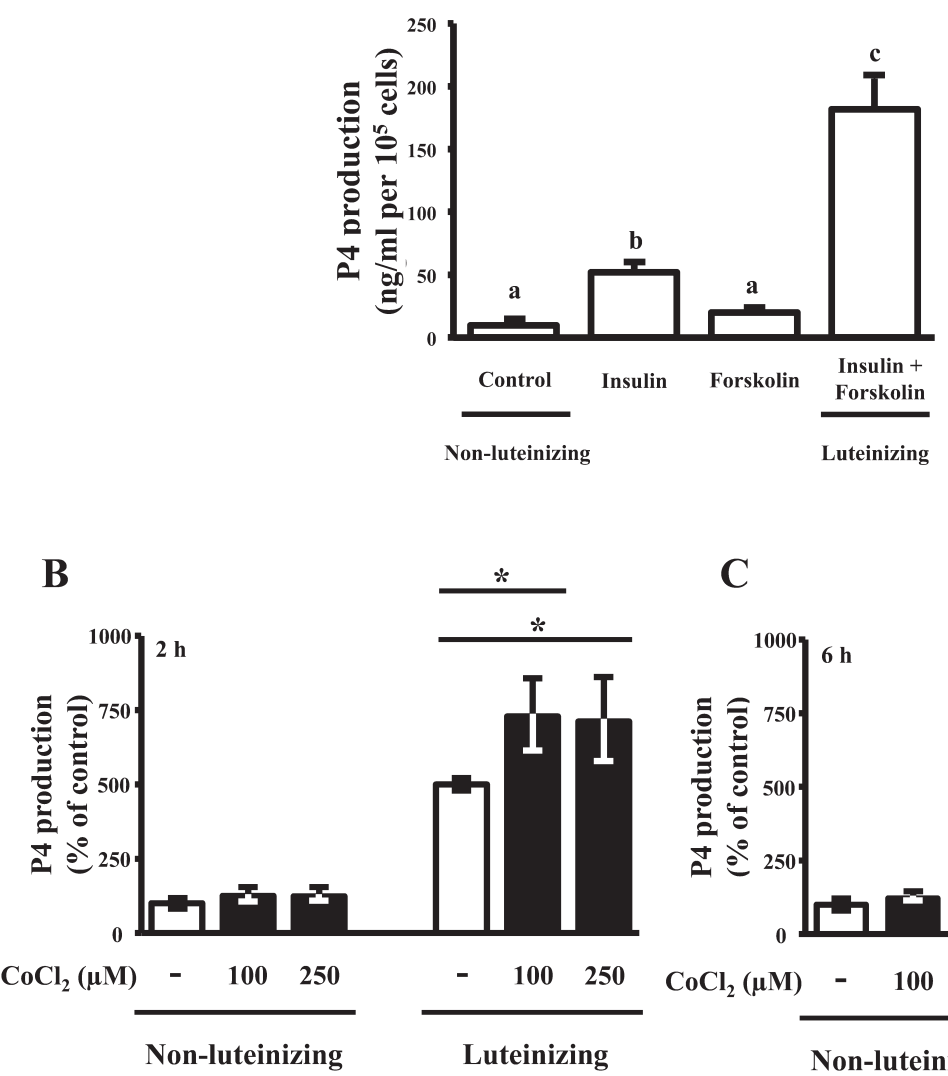

C

D

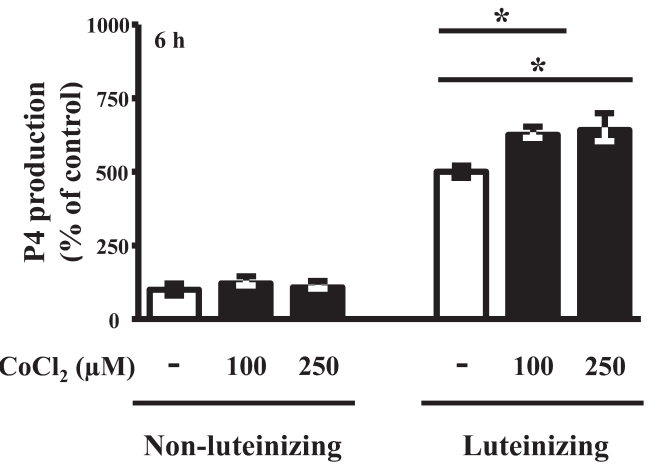

$\mathbf{E}$
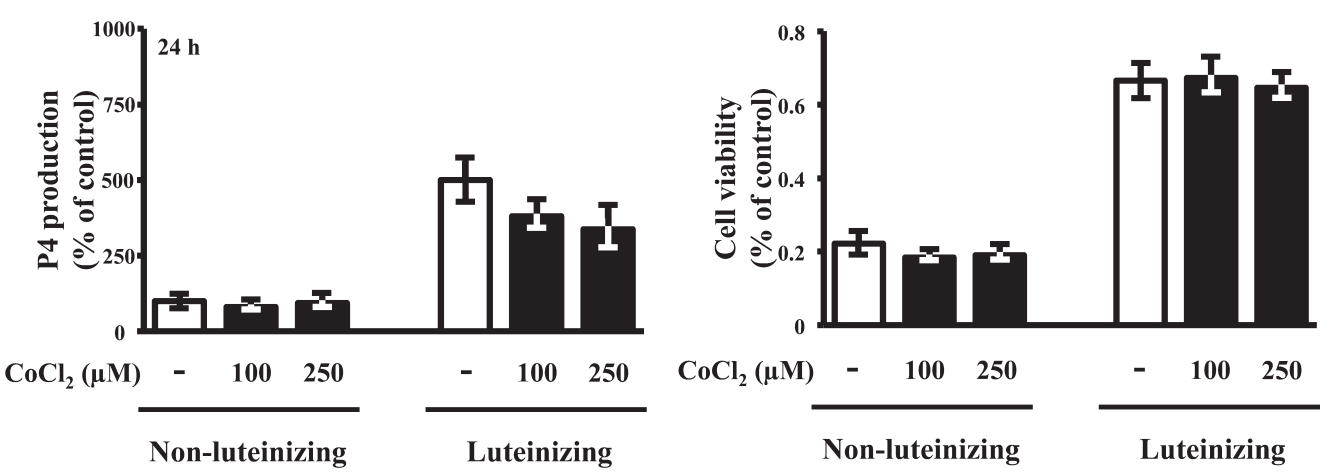

Fig. 1. Effects of $\mathrm{CoCl}_{2}$ on $\mathrm{P} 4$ production by luteinizing and non-luteinizing GCs and on cell viability. To prepare luteinizing and non-luteinizing GCs, we cultured the cells at $20 \% \mathrm{O}_{2}$ in the presence of insulin $(2 \mu \mathrm{g} / \mathrm{ml})$ and/or forskolin $(10 \mu \mathrm{M})$ for $24 \mathrm{~h}$. P4 production was then quantified (A). To measure P4 production, the culture media were collected for an enzyme immunoassay (EIA) of P4, while the cultured cells were collected for measurement of DNA content by spectrophotometry to normalize the P4 concentration. The cells cultured without insulin and forskolin were defined as non-luteinizing GCs, while the cells cultured in the presence of insulin in combination with forskolin were defined as luteinizing GCs (control: non-luteinizing GCs, insulin + forskolin: luteinizing GCs). After $24 \mathrm{~h}$, the luteinizing and non-luteinizing GCs were cultured with or without $\mathrm{CoCl}_{2}(100$ or $250 \mu \mathrm{M})$ for $2(\mathrm{~B}), 6(\mathrm{C})$, or $24 \mathrm{~h}(\mathrm{D})$ to determine the effect of $\mathrm{CoCl}_{2}$ on $\mathrm{P} 4$ production. P4 production value was shown as a percentage of control (cultured non-luteinizing $\mathrm{GCs}$ without $\mathrm{CoCl}_{2}$ ). (E) The effect of $\mathrm{CoCl}_{2}$ on cell viability was also determined. The cultured cells were incubated with the WST-1 reagent for $4 \mathrm{~h}$ at $38^{\circ} \mathrm{C}$, then the absorbance was read using a microplate reader. The data are shown as a percentage of control (cultured cells without $\mathrm{CoCl}_{2}$ ) for each group: the group of luteinizing GCs and the group of non-luteinizing GCs. Different letters $(\mathrm{A})$ and asterisks $(\mathrm{B}, \mathrm{C})$ indicate significant differences $(\mathrm{P}<0.05)$ between groups as determined by one-way ANOVA. All data represent mean \pm SEM of four independent experiments. 
A
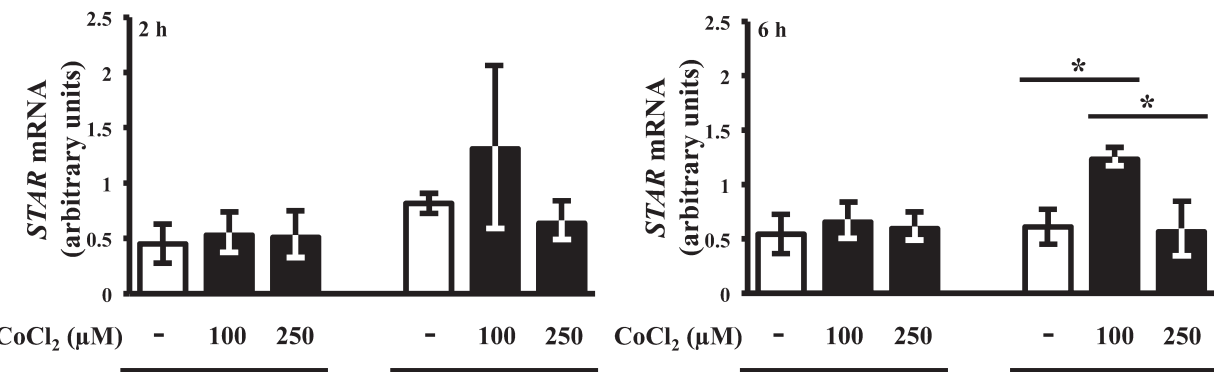

$\mathrm{CoCl}_{2}(\mu \mathrm{M}) \quad-\quad 100250$

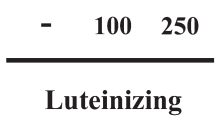

Non-luteinizing

Luteinizing

B
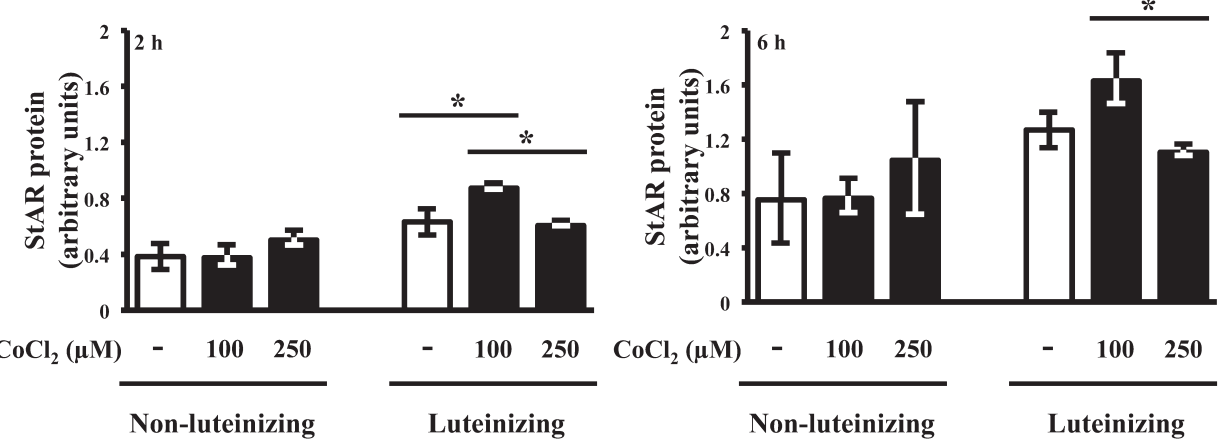

C
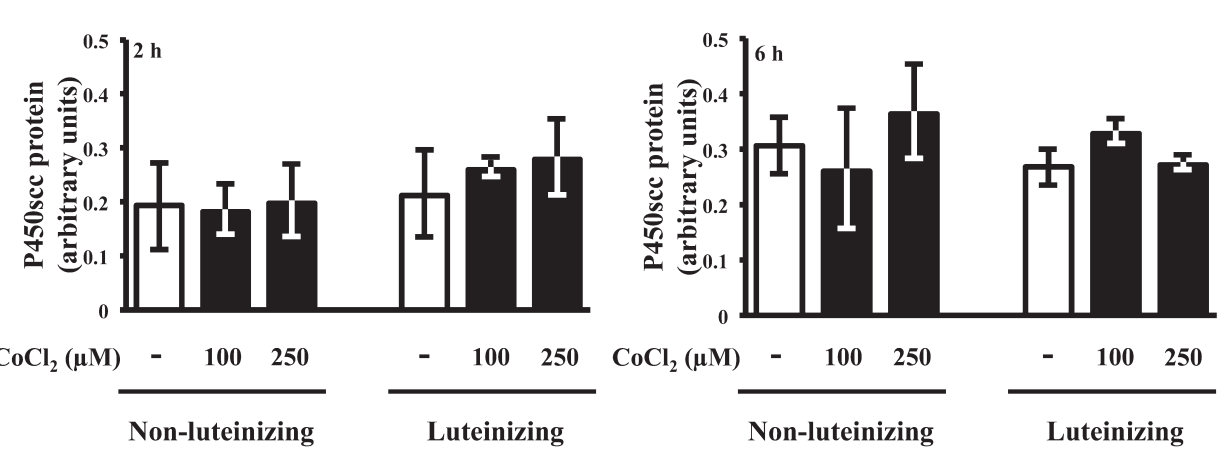

D
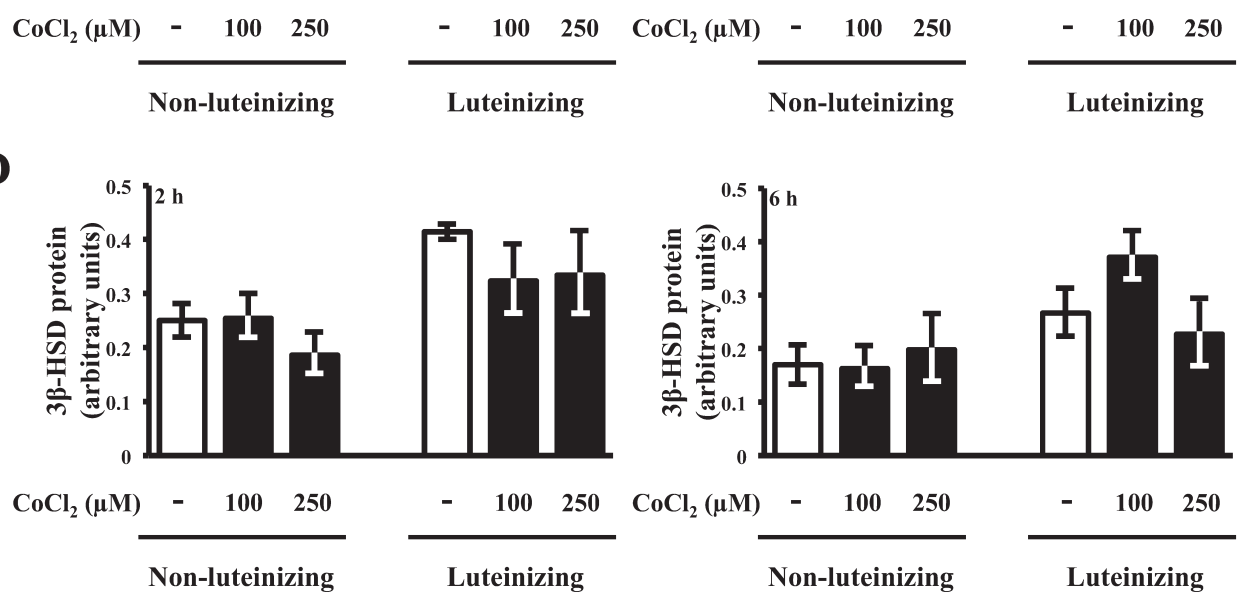

Fig. 2. Effects of $\mathrm{CoCl}_{2}$ on the expression levels of StAR, P450scc, and 3ß-HSD in non-luteinizing and luteinizing GCs. These cells were incubated with or without $\mathrm{CoCl}_{2}(100$ or $250 \mu \mathrm{M})$ for 2 or $6 \mathrm{~h}$. Total RNA was then extracted from harvested cells to determine mRNA expression of STAR (A) by real-time PCR. The amount of STAR mRNA is expressed relative to the amount of $18 S r R N A$ mRNA. The protein expression levels of StAR (B), P450scc (C), and 3 $\beta$-HSD (D) were determined by western blotting. All the protein expression levels are expressed relative to the level of $\beta$-actin protein expression. The blot was incubated with primary antibodies against StAR, P450scc, 33-HSD, or $\beta$-actin and then incubated with a secondary antibody conjugated with HRP. The resultant signal was detected by chemiluminescence and quantitated by computer-assisted densitometry. Asterisks indicate significant differences $(\mathrm{P}<0.05)$ between groups - the group of luteinizing GCs and the group of non-luteinizing GCs - as determined by one-way ANOVA. All data represent mean \pm SEM of four independent experiments. 
$2 \mathrm{~h}$

HIF-1 $\alpha$ (120 kDa)

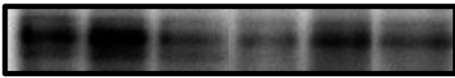

StAR (32 kDa)

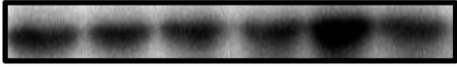

$\beta$-actin (42 kDa)
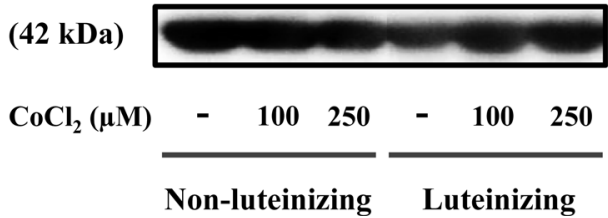

$6 \mathrm{~h}$

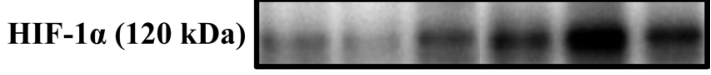

StAR (32 kDa)

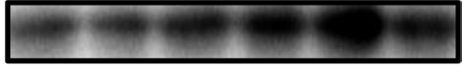

$\beta$-actin (42 kDa)
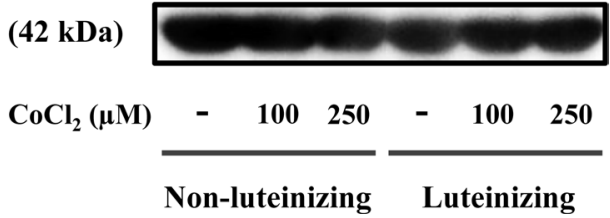

Fig. 3. Effects of $\mathrm{CoCl}_{2}$ on HIF-1 $\alpha$ and StAR protein expression levels. The luteinizing and non-luteinizing $\mathrm{GCs}$ were incubated with or without $\mathrm{CoCl} 2$ $(100$ or $250 \mu \mathrm{M})$ for $2 \mathrm{~h}$ or $6 \mathrm{~h}$. The cells were then collected to determine HIF-1 $\alpha$ and StAR protein expression by western blotting. The blot was incubated with primary antibodies against HIF- $1 \alpha$, StAR, or $\beta$-actin and then with a secondary antibody conjugated with HRP. The resultant signals were detected by chemiluminescence and quantitated by computer-assisted densitometry.

previous findings [26], culturing of luteinizing GCs under $10 \%$ $\mathrm{O}_{2}$ significantly increased $\mathrm{P} 4$ production after 24 h (Fig. $5 \mathrm{~A} ; \mathrm{P}<$ 0.05). Culturing of luteinizing GCs under $10 \% \mathrm{O}_{2}$ also increased the expression of STAR mRNA (Fig. 5C; P $<0.05$ ) and protein (Fig. 5D and 5E; $\mathrm{P}<0.05$ ) in comparison with cultivation under $20 \% \mathrm{O}_{2}$. Echinomycin attenuated the $10 \% \mathrm{O}_{2}$ effects that increased $\mathrm{P} 4$ production (Fig. 5B; $\mathrm{P}<0.05$ ) and the increased expression of STAR mRNA (Fig. 5C; $\mathrm{P}<0.05$ ) and protein (Fig. 5D and 5E; $\mathrm{P}<$ $0.05)$ after $24 \mathrm{~h}$ in luteinizing GCs.

\section{Discussion}

LH pulses increase gradually and result in an LH surge. The increasing LH pulses stimulate dominant follicle growth, ovulation, and luteinization [40, 41]. In the follicle compartment before ovulation, GCs and the oocyte develop in an avascular environment that is considered to be hypoxic [2-4]. The microenvironment of the ruptured follicle is also thought to be hypoxic immediately after ovulation [5]. Thus, luteinization and hypoxia seem to occur simultaneously the time of ovulation. Luteinization is defined as the process in which GCs and theca cells differentiate into luteal cells and then produce a large amount of $\mathrm{P} 4$, which is important for establishing pregnancy [10, 42-44]. We previously suggested that hypoxic conditions promote the progression and completion of luteinization by enhancing P4 synthesis in bovine GCs [26]. Using the same model of bovine cultured luteinizing GCs, we found in the present study that enhancement of $\mathrm{P} 4$ synthesis either by hypoxia $(10 \%$ $\mathrm{O}_{2}$ ) or by $\mathrm{CoCl}_{2}$ is attenuated by the addition of echinomycin, the inhibitor of HIF-1 DNA binding [18], suggesting that HIF-1-mediated P4 upregulation takes place during luteinization. The present results strongly support the idea that hypoxic conditions are important for luteinization and for steroidogenesis during this period.

In the present study, we used $\mathrm{CoCl}_{2}$ to mimic hypoxia because treatment with this compound has been shown to successfully mimic hypoxia in other studies $[8,20,45] . \mathrm{CoCl}_{2}(100$ and 250 $\mu \mathrm{M}$ ) increased $\mathrm{P} 4$ production after 2 and $6 \mathrm{~h}$ in luteinizing GCs. Concentrations of $\mathrm{CoCl}_{2}$ up to $500 \mu \mathrm{M}$ have been used in some studies on HIF-1 $\alpha[46,47]$. Simultaneously with the increase in P4 production, $100 \mu \mathrm{M} \mathrm{CoCl}_{2}$ can also sufficient to increase the HIF-1 $\alpha$ protein level after 2 and $6 \mathrm{~h}$. In addition, the present results indicated that $\mathrm{CoCl}_{2}$ has the same effects as $10 \% \mathrm{O}_{2}$ does on HIF- $1 \alpha$ protein expression and on $\mathrm{P} 4$ production in luteinizing GCs, as shown in our previous study [26]. This low-oxygen condition may represent the $\mathrm{O}_{2}$ condition in the cells during luteinization. This finding suggests that low-oxygen conditions promote $\mathrm{P} 4$ production during rather than before luteinization.

Our results showed that treatment of luteinizing GCs with $\mathrm{CoCl}_{2}$ for $24 \mathrm{~h}$ tended to decrease their P4 production. Similarly, $500 \mu \mathrm{M}$ $\mathrm{CoCl}_{2}$ and $1 \% \mathrm{O}_{2}$ for $24 \mathrm{~h}$ inhibited $\mathrm{P} 4$ synthesis in bovine luteinized GCs obtained from the largest follicle [48]. Hypoxia seems to have a biphasic effect on steroidogenesis depending on oxygen tension and on duration of exposure to hypoxia. The induction of apoptosis by hypoxia was found to be most pronounced after exposure of normal cells or tissues to severe hypoxia [49, 50]. Hypoxia-mimicking agents, such as $\mathrm{CoCl}_{2}$, and low oxygen tension are also known to induce apoptosis in a number of cell types [49]. Nevertheless, the degrees of apoptosis in the $\mathrm{GCs}$ exposed to $\mathrm{CoCl}_{2}$ or to low oxygen tension was not assessed in the present study, and further studies would be required to address this issue.

StAR is one of the key proteins in P4 synthesis. In GCs, StAR expression signals early functional maturation of an ovarian antral follicle [51]. During luteinization, StAR expression is upregulated in order to transfer cholesterol from the outer to inner mitochondrial membrane [11, 52-56]. We confirmed that luteinizing GCs in our present model show higher expression of StAR in comparison with non-luteinizing GCs as shown in our previous study [26]. In luteinizing $\mathrm{GCs}$, expression of the StAR protein is increased by $100 \mu \mathrm{M} \mathrm{CoCl}_{2}$ after 2 or $6 \mathrm{~h}$ of incubation and by $10 \% \mathrm{O}_{2}$ after $24 \mathrm{~h}$. The observed exposure duration necessary for $\mathrm{CoCl}_{2}$ or $10 \% \mathrm{O}_{2}$ to increase StAR expression in luteinizing GCs is in agreement with their exposure time necessary to increase $\mathrm{P} 4$ production. One of the reasons why $\mathrm{CoCl}_{2}$ increased $\mathrm{P} 4$ production (Fig. $1 \mathrm{~B}$ and $1 \mathrm{C}$ ) together with mRNA (Fig. 2A) and protein expression of StAR (Fig. 2B) during shorter culture periods ( 2 and $6 \mathrm{~h}$ ) than $10 \% \mathrm{O}_{2}$ did $(24 \mathrm{~h}$; Fig. $5 \mathrm{~A}-\mathrm{E})$ is that the direct inhibition of HIF- $1 \alpha$ protein degradation by $\mathrm{CoCl}_{2}$ [20] is more effective than the influence of $10 \% \mathrm{O}_{2}$ on HIF- $1 \alpha$ protein 
A

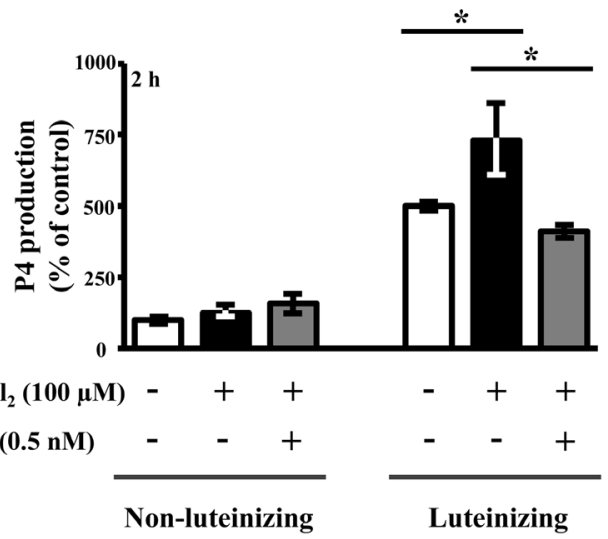

B

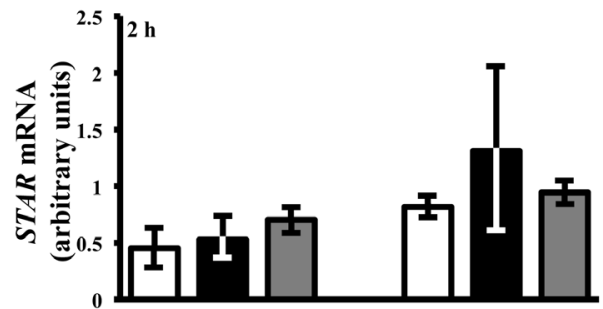

$\mathrm{CoCl}_{2}(100 \mu \mathrm{M})-\quad+\quad+$ $\operatorname{Ech}(0.5 \mathrm{nM})$ Non-luteinizing

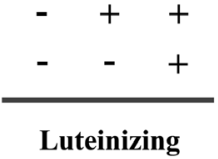

C

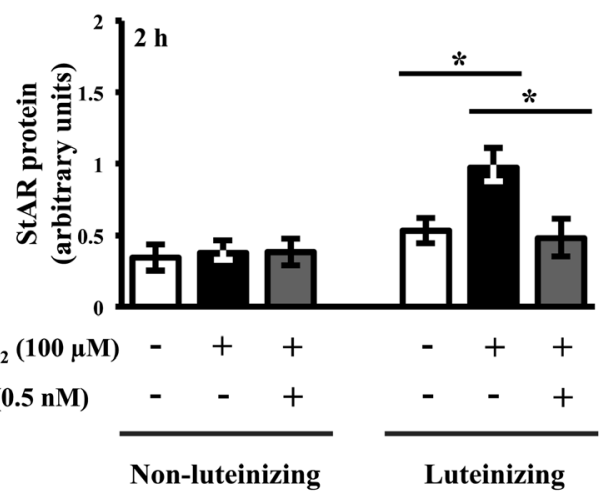

D

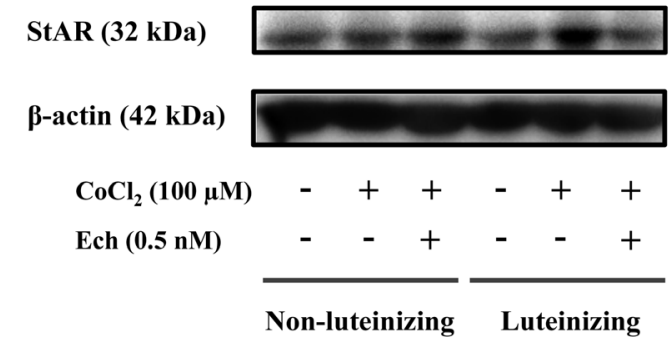

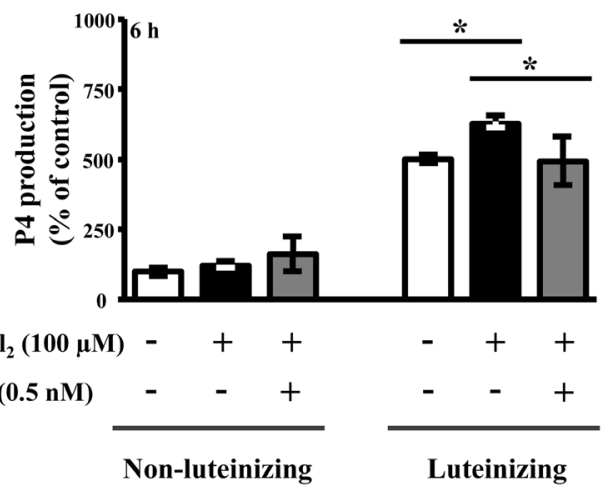
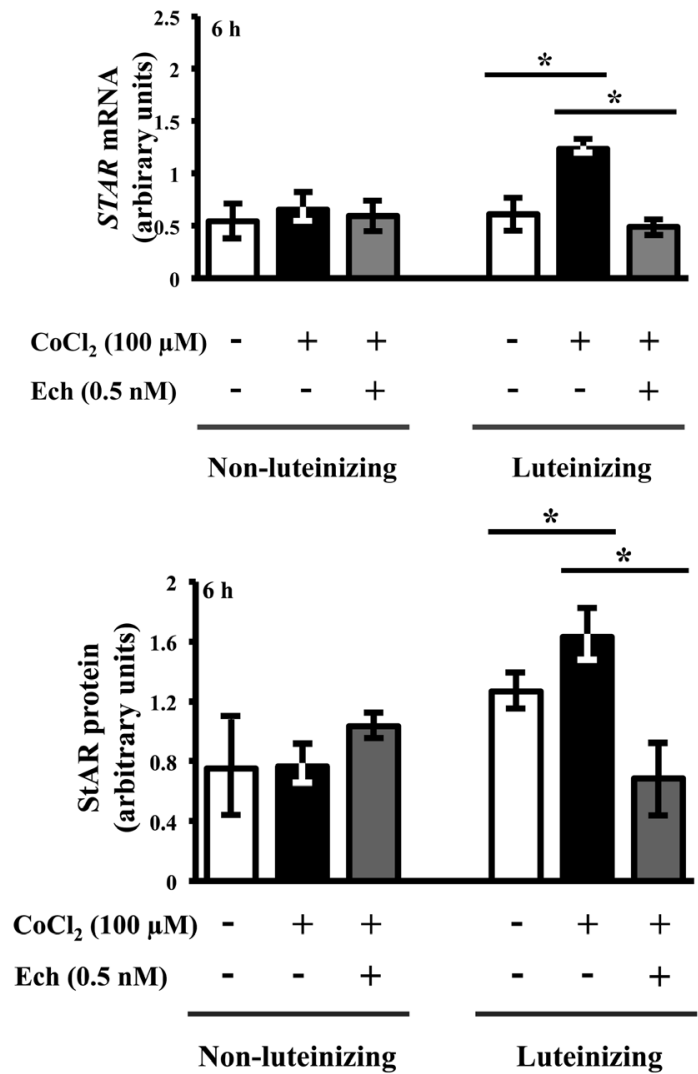

Fig. 4.

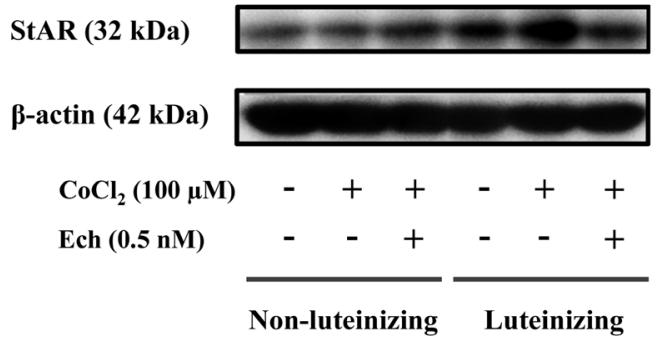


accumulation. On the other hand, neither $\mathrm{CoCl}_{2}$ nor $10 \% \mathrm{O}_{2}$ affected $\mathrm{P} 450 \mathrm{scc}$ and $3 \beta$-HSD expression levels. These results suggest that hypoxic conditions promote $\mathrm{P} 4$ production via the upregulation of StAR during luteinization.

Echinomycin is a DNA-binding agent that binds to the HRE site within the promoters of HIF-1's target genes and selectively inhibits the binding activity of HIF-1 $\alpha$ [18]. In rats undergoing gonadotropin-induced ovulation, blockage of HIF-1 activity by echinomycin profoundly impairs the rupture of preovulatory follicles and reduces VEGF expression [2], suggesting that HIF-1 performs important functions in ovulation, especially in steroidogenesis during luteinization. Our finding in the present study that echinomycin attenuated hypoxia-enhanced $\mathrm{P} 4$ production and StAR expression in luteinizing GCs suggests that the increase in P4 synthesis during luteinization is stimulated by the transcription-regulatory activity of HIF-1. All these results may explain additional roles of hypoxia and HIF-1 around approximately at the time of ovulation, especially steroidogenesis, which is required not only for ovulation but also for luteinization.

In our previous studies $[57,58]$, we reported that hypoxia also affects luteolysis. Hypoxia has been shown to induce corpus luteum regression and to promote apoptosis of luteal cells, in which an oxygen deficiency or low-oxygen conditions suppress $\mathrm{P} 4$ production. It seems that hypoxia has a biphasic effect on $\mathrm{P} 4$ production during luteinization and in luteolysis depending on the differentiation status of the cells. The cells used in the present study were early-growing luteal cells, which start producing a large amount of P4, whereas the cells analyzed in our previous study were luteal cells obtained from a mid-stage corpus luteum, which produce the largest amount of P4.

In agreement with our present results, it has been reported that $10 \% \mathrm{O}_{2}$ stimulates STAR gene transcription in immortalized (KK1) murine GCs, and that HIF- $1 \alpha$ seems to be actively involved in direct regulation of basal and dibutyryl cyclic AMP-stimulated StAR protein expression by binding to the proximal murine STAR promoter [59]. Further studies are needed to explain why hypoxic conditions and HIF-1 affected P4 synthesis in luteinizing GCs but not in non-luteinizing GCs in the present study. In conclusion, overall, our findings suggest that the hypoxia-induced increase in $\mathrm{P} 4$ production and in StAR expression in bovine cultured luteinizing GCs is mediated by HIF-1. In other words, by enhancing P4 synthesis, HIF-1 may play as an important factor in the progression of luteinization by enhancing P4 synthesis.

\section{Acknowledgments}

This research was supported by a Grant-in-Aid for Scientific
Research (No. 24380155) of the Japan Society for the Promotion Science (JSPS). Fadhillah is supported by a scholarship from the Ministry of Education, Culture, Sports, Science and Technology of Japan.

\section{References}

1. Moor RM, Seamark RF. Cell signaling, permeability, and microvasculatory changes during antral follicle development in mammals. J Dairy Sci 1986; 69: 927-943. [Medline] [CrossRef]

2. Kim J, Bagchi IC, Bagchi MK. Signaling by hypoxia-inducible factors is critical for ovulation in mice. Endocrinology 2009; 150: 3392-3400. [Medline] [CrossRef]

3. Suzuki T, Sasano H, Takaya R, Fukaya T, Yajima A, Nagura H. Cyclic changes of vasculature and vascular phenotypes in normal human ovaries. Hum Reprod 1998; 13: 953-959. [Medline] [CrossRef]

4. Redmer DA, Reynolds LP. Angiogenesis in the ovary. Rev Reprod 1996; 1: 182-192. [Medline] [CrossRef]

5. Amselgruber WM, Schäfer M, Sinowatz F. Angiogenesis in the bovine corpus luteum: an immunocytochemical and ultrastructural study. Anat Histol Embryol 1999; 28: 157-166. [Medline] [CrossRef]

6. Wang GL, Jiang BH, Rue EA, Semenza GL. Hypoxia-inducible factor 1 is a basic-helixloop-helix-PAS heterodimer regulated by cellular $\mathrm{O}_{2}$ tension. Proc Natl Acad Sci USA 1995; 92: 5510-5514. [Medline] [CrossRef]

7. Salceda S, Caro J. Hypoxia-inducible factor $1 \alpha$ (HIF-1 $\alpha$ ) protein is rapidly degraded by the ubiquitin-proteasome system under normoxic conditions. Its stabilization by hypoxia depends on redox-induced changes. J Biol Chem 1997; 272: 22642-22647. [Medline] [CrossRef]

8. Yalu R, Oyesiji AE, Eisenberg I, Imbar T, Meidan R. HIF1A-dependent increase in endothelin 2 levels in granulosa cells: role of hypoxia, LH/cAMP, and reactive oxygen species. Reproduction 2015; 149: 11-20. [Medline] [CrossRef]

9. Tam KK, Russell DL, Peet DJ, Bracken CP, Rodgers RJ, Thompson JG, Kind KL. Hormonally regulated follicle differentiation and luteinization in the mouse is associated with hypoxia inducible factor activity. Mol Cell Endocrinol 2010; 327: 47-55. [Medline] [CrossRef]

10. Gradin K, McGuire J, Wenger RH, Kvietikova I, fhitelaw ML, Toftgård R, Tora L, Gassmann M, Poellinger L. Functional interference between hypoxia and dioxin signal transduction pathways: competition for recruitment of the Arnt transcription factor. $\mathrm{Mol}$ Cell Biol 1996; 16: 5221-5231. [Medline] [CrossRef]

11. Wiesener MS, Turley H, Allen WE, Willam C, Eckardt KU, Talks KL, Wood SM, Gatter KC, Harris AL, Pugh CW, Ratcliffe PJ, Maxwell PH. Induction of endothelial PAS domain protein-1 by hypoxia: characterization and comparison with hypoxiainducible factor-1alpha. Blood 1998; 92: 2260-2268. [Medline]

12. Linden T, Katschinski DM, Eckhardt K, Scheid A, Pagel H, Wenger RH. The antimycotic ciclopirox olamine induces HIF-1alpha stability, VEGF expression, and angiogenesis. FASEB J 2003; 17: 761-763. [Medline]

13. Yuan Y, Hilliard G, Ferguson T, Millhorn DE. Cobalt inhibits the interaction between hypoxia-inducible factor-alpha and von Hippel-Lindau protein by direct binding to hypoxia-inducible factor-alpha. J Biol Chem 2003; 278: 15911-15916. [Medline] [CrossRef]

14. Boonyaprakob U, Gadsby JE, Hedgpeth V, Routh PA, Almond GW. Expression and localization of hypoxia inducible factor- $1 \alpha$ mRNA in the porcine ovary. Can J Vet Res 2005; 69: 215-222. [Medline]

15. van den Driesche S, Myers M, Gay E, Thong KJ, Duncan WC. HCG up-regulates hypoxia inducible factor-1 alpha in luteinized granulosa cells: implications for the hormonal regulation of vascular endothelial growth factor A in the human corpus luteum. Mol Hum Reprod 2008; 14: 455-464. [Medline] [CrossRef]

16. Duncan WC, van den Driesche S, Fraser HM. Inhibition of vascular endothelial growth factor in the primate ovary up-regulates hypoxia-inducible factor-1alpha in the follicle and

Fig. 4. The effect of echinomycin (Ech) on $\mathrm{CoCl}_{2}$-enhanced $\mathrm{P} 4$ synthesis. The luteinizing and non-luteinizing GCs were cultured with or without 0.5 $\mathrm{nM}$ echinomycin in the presence of $100 \mu \mathrm{M} \mathrm{CoCl}_{2}$ for 2 or $6 \mathrm{~h}$. To determine P4 production, the culture media were collected for EIA to measure P4 concentration, while the cultured cells were collected for analysis of DNA content by a spectrophotometric method to normalize the P4 concentrations. P4 amounts are shown as a percentage of the control (cultured non-luteinizing GCs without $\left.\mathrm{CoCl}_{2}\right)(\mathrm{A})$. STAR mRNA expression was determined by real-time PCR (B). The amount of STAR mRNA is expressed relative to the amount of 18SrRNA mRNA. The protein expression of StAR was determined by western blotting $(\mathrm{C})$. The protein level is expressed relative to the protein expression of $\beta$-actin. Asterisks indicate significant differences $(\mathrm{P}<0.05)$ between groups - the group of luteinizing GCs and the group of non-luteinizing GCs - as determined by one-way ANOVA. All data represent mean \pm SEM of four independent experiments. Representative examples of western blotting for StAR and $\beta$-actin are shown in (D). 
A

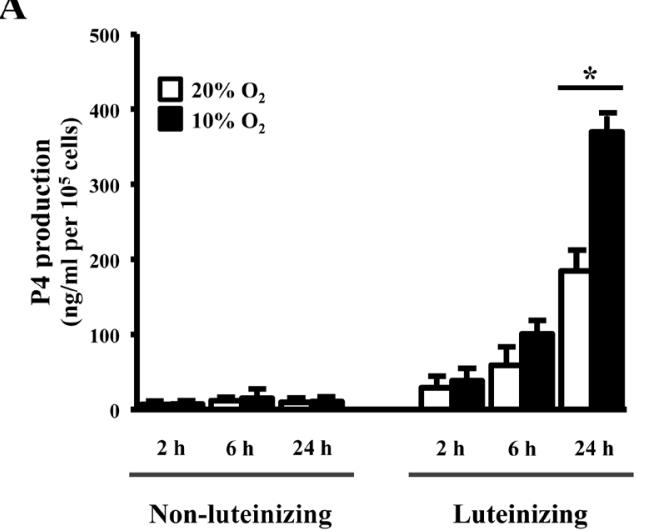

B

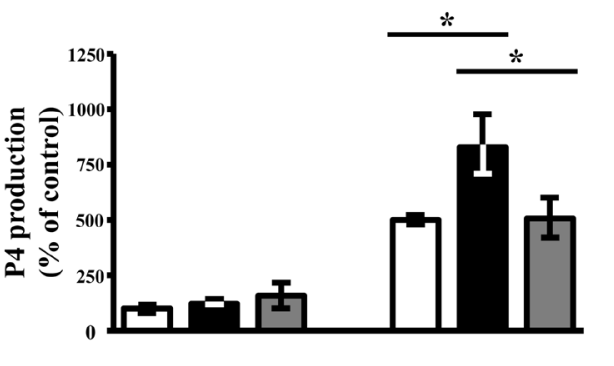

C

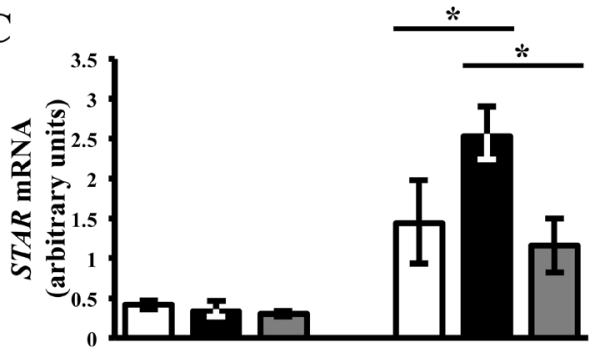

$\begin{array}{llll}\mathrm{O}_{2} \text { level }(\%) & 20 & 10 & 10\end{array}$

$\begin{array}{lll}20 & 10 & 10\end{array}$

$\begin{array}{llll}\mathrm{O}_{2} \text { level }(\%) & 20 & 10 & 10\end{array}$

$\operatorname{Ech}(0.5$ nM) $\quad-\quad \quad-\quad+$

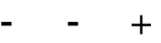

Non-luteinizing

Luteinizing

$\operatorname{Ech}(0.5 \mathrm{nM})$

$\begin{array}{ccc}20 & 10 & 10 \\ - & - & +\end{array}$

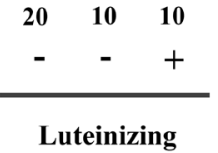

D

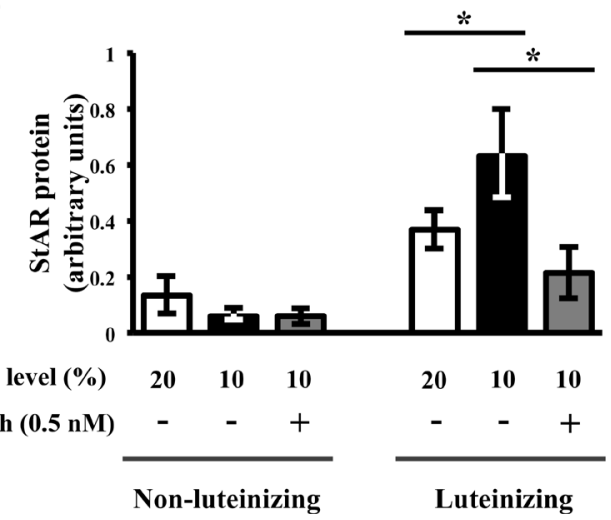

E

StAR (32 kDa)

$\beta$-actin (42 kDa)

$\mathrm{O}_{2}$ level (\%)

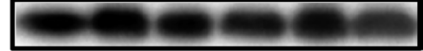

$\operatorname{Ech}(0.5 \mathrm{nM})$

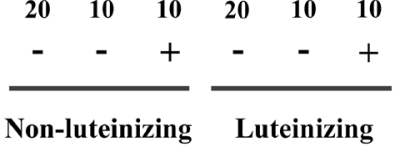

Non-luteinizing

Luteinizing

Fig. 5. The effect of echinomycin (Ech) on $10 \% \mathrm{O}_{2}$-enhanced $\mathrm{P} 4$ synthesis. The luteinizing and non-luteinizing GCs were cultured at $20 \% \mathrm{O}{ }_{2}$ as a control or at $10 \% \mathrm{O}_{2}$ as low-oxygen tension for 2,6 , or $24 \mathrm{~h}$ to quantify P4 production (A). To this end, the culture media were collected for EIA of P4, while the cultured cells were collected for measurement of DNA content by a spectrophotometric method to normalize the P4 concentrations. Other batches of luteinizing and non-luteinizing GCs were cultured at $20 \%$ or $10 \% \mathrm{O}_{2}$ with or without $0.5 \mathrm{nM}$ echinomycin for $24 \mathrm{~h}$, then $\mathrm{P} 4$ production was measured (B). P4 amounts are shown as a percentage of the control (cultured non-luteinizing GCs cells at $20 \% \mathrm{O}_{2}$ without echinomycin). STAR mRNA expression was quantified by real-time PCR (C), and StAR protein expression was determined by western blotting (D). Asterisks indicate significant differences $(\mathrm{P}<0.05)$ between groups — the group of luteinizing GCs and the group of non-luteinizing GCs - as determined by one-way ANOVA. All data represent mean \pm SEM of four independent experiments. Representative examples of western blotting for StAR and $\beta$-actin are shown in $(\mathrm{E})$. 
corpus luteum. Endocrinology 2008; 149: 3313-3320. [Medline] [CrossRef]

17. Meidan R, Klipper E, Zalman Y, Yalu R. The role of hypoxia-induced genes in ovarian angiogenesis. Reprod Fertil Dev 2013; 25: 343-350. [Medline] [CrossRef]

18. Kong D, Park EJ, Stephen AG, Calvani M, Cardellina JH, Monks A, Fisher RJ, Shoemaker RH, Melillo G. Echinomycin, a small-molecule inhibitor of hypoxiainducible factor-1 DNA-binding activity. Cancer Res 2005; 65: 9047-9055. [Medline] [CrossRef]

19. Concannon P, Hansel W, Mcentee K. Changes in LH, progesterone and sexual behavior associated with preovulatory luteinization in the bitch. Biol Reprod 1977; 17: 604-613. [Medline] [CrossRef]

20. Clark BJ, Wells J, King SR, Stocco DM. The purification, cloning, and expression of a novel luteinizing hormone-induced mitochondrial protein in MA-10 mouse Leydig tumor cells. Characterization of the steroidogenic acute regulatory protein (StAR). J Biol Chem 1994; 269: 28314-28322. [Medline]

21. Clark BJ, Soo SC, Caron KM, Ikeda Y, Parker KL, Stocco DM. Hormonal and developmental regulation of the steroidogenic acute regulatory protein. Mol Endocrinol 1995; 9: 1346-1355. [Medline]

22. Stocco DM. A StAR search: implications in controlling steroidgenesis. Biol Reprod 1997; 56: 328-336. [Medline] [CrossRef]

23. Juengel JL, Niswender GD. Molecular regulation of luteal progesterone synthesis in domestic ruminants. J Reprod Fertil Suppl 1999; 54: 193-205. [Medline]

24. Niswender GD. Molecular control of luteal secretion of progesterone. Reproduction 2002; 123: 333-339. [Medline] [CrossRef]

25. Murphy BD, Gévry N, Ruiz-Cortés T, Coté F, Downey BR, Sirois J. Formation and early development of the corpus luteum in pigs. Reprod Suppl 2001; 58(Suppl): 47-63. [Medline]

26. Fadhillah YS, Yoshioka S, Nishimura R, Okuda K. Hypoxia promotes progesterone synthesis during luteinization in bovine granulosa cells. J Reprod Dev 2014; 60: 194-201. [Medline] [CrossRef]

27. Savion N, Lui GM, Laherty R, Gospodarowicz D. Factors controlling proliferation and progesterone production by bovine granulosa cells in serum-free medium. Endocrinology 1981; 109: 409-420. [Medline] [CrossRef]

28. Veldhuis JD, Kolp LA. Mechanisms subserving insulins differentiating actions on progestin biosynthesis by ovarian cells: studies with cultured swine granulosa cells. Endocrinology 1985; 116: 651-659. [Medline] [CrossRef]

29. McArdle CA, Holtorf AP. Oxytocin and progesterone release from bovine corpus luteal cells in culture: effects of insulin-like growth factor I, insulin, and prostaglandins. Endocrinology 1989; 124: 1278-1286. [Medline] [CrossRef]

30. Saumande J. Culture of bovine granulosa cells in a chemically defined serum-free medium: the effect of insulin and fibronectin on the response to FSH. J Steroid Biochem Mol Biol 1991; 38: 189-196. [Medline] [CrossRef]

31. Gong JG, McBride D, Bramley TA, Webb R. Effects of recombinant bovine somatotrophin, insulin-like growth factor-I and insulin on the proliferation of bovine granulosa cells in vitro. $J$ Endocrinol 1993; 139: 67-75. [Medline] [CrossRef]

32. Lioutas C, Einspanier A, Kascheike B, Walther N, Ivell R. An autocrine progesterone positive feedback loop mediates oxytocin upregulation in bovine granulosa cells during luteinization. Endocrinology 1997; 138: 5059-5062. [Medline] [CrossRef]

33. Meidan R, Altstein M, Girsh E. Biosynthesis and release of oxytocin by granulosa cells derived from preovulatory bovine follicles: effects of forskolin and insulin-like growth factor-I. Biol Reprod 1992; 46: 715-720. [Medline] [CrossRef]

34. Fujita Y, Okuda K, Horikawa K, Naito C. In vitro differentiation of bovine granulosa cells obtained from small antral follicles. J Reprod Dev 1996; 42: 133-138. [CrossRef]

35. Okuda K, Uenoyama Y, Lee KW, Sakumoto R, Skarzynski DJ. Progesterone stimulation by prostaglandin $\mathrm{F} 2 \alpha$ involves the protein kinase $\mathrm{C}$ pathway in cultured bovine luteal cells. J Reprod Dev 1998; 44: 79-84. [CrossRef]

36. Labarca C, Paigen K. A simple, rapid, and sensitive DNA assay procedure. Anal Biochem 1980; 102: 344-352. [Medline] [CrossRef]

37. Sakumoto R, Komatsu T, Kasuya E, Saito T, Okuda K. Expression of mRNAs for interleukin-4, interleukin-6 and their receptors in porcine corpus luteum during the estrous cycle. Domest Anim Endocrinol 2006; 31: 246-257. [Medline] [CrossRef]

38. Osnes T, Sandstad O, Skar V, Osnes M, Kierulf P. Total protein in common duct bile measured by acetonitrile precipitation and a micro bicinchoninic acid (BCA) method. Scand J Clin Lab Invest 1993; 53: 757-763. [Medline] [CrossRef]

39. Mosmann T. Rapid colorimetric assay for cellular growth and survival: application to proliferation and cytotoxicity assays. J Immunol Methods 1983; 65: 55-63. [Medline] [CrossRef]

40. Walters DL, Schams D, Schallenberger E. Pulsatile secretion of gonadotrophins, ovarian steroids and ovarian oxytocin during the luteal phase of the oestrous cycle in the cow. J Reprod Fertil 1984; 71: 479-491. [Medline] [CrossRef]

41. Schallenberger E, Schams D, Bullermann B, Walters DL. Pulsatile secretion of gonadotrophins, ovarian steroids and ovarian oxytocin during prostaglandin-induced regression of the corpus luteum in the cow. $J$ Reprod Fertil 1984; 71: 493-501. [Medline] [CrossRef]

42. Lipner H. Mechanism of ovulation. In: Knobil E, Neill J (eds.), The Physiology of Reproduction. New York: Raven Press; 1988: 447-488.

43. Niswender GD, Nett TM. The corpus luteum and its control In: Knobil E, Neill J (eds.), The Physiology of Reproduction. New York: Raven Press; 1988: 489-525.

44. Cavender JL, Murdoch WJ. Morphological studies of the microcirculatory system of periovulatory ovine follicles. Biol Reprod 1988; 39: 989-997. [Medline] [CrossRef]

45. Zhang J, Zhang Z, Wu Y, Chen L, Luo Q, Chen J, Huang X, Cheng Y, Wang Z. Regulatory effect of hypoxia-inducible factor- $1 \alpha$ on hCG-stimulated endothelin-2 expression in granulosa cells from the PMSG-treated rat ovary. J Reprod Dev 2012; 58: 678-684. [Medline] [CrossRef]

46. Cho J, Kim D, Lee S, Lee Y. Cobalt chloride-induced estrogen receptor alpha downregulation involves hypoxia-inducible factor-1alpha in MCF-7 human breast cancer cells. Mol Endocrinol 2005; 19: 1191-1199. [Medline] [CrossRef]

47. Ardyanto TD, Osaki M, Tokuyasu N, Nagahama $\mathbf{Y}$, Ito $\mathbf{H}$. $\mathrm{CoCl}_{2}$-induced $\mathrm{HIF}$-1alpha expression correlates with proliferation and apoptosis in MKN-1 cells: a possible role for the PI3K/Akt pathway. Int J Oncol 2006; 29: 549-555. [Medline]

48. Jiang YF, Tsui KH, Wang PH, Lin CW, Wang JY, Hsu MC, Chen YC, Chiu CH. Hypoxia regulates cell proliferation and steroidogenesis through protein kinase A signaling in bovine corpus luteum. Anim Reprod Sci 2011; 129: 152-161. [Medline] [CrossRef]

49. Greijer AE, van der Wall E. The role of hypoxia inducible factor 1 (HIF-1) in hypoxia induced apoptosis. J Clin Pathol 2004; 57: 1009-1014. [Medline] [CrossRef]

50. Hang X, Li P, Li Z, Qu W, Yu Y, Li H, Shen Z, Zheng H, Gao Y, Wu Y, Deng M, Sun Z, Zhang C. Transcription and splicing regulation in human umbilical vein endothelia cells under hypoxic stress conditions by exon array. BMC Genomics 2009; 10: 126. [Medline] [CrossRef]

51. Thompson WE, Powell J, Thomas KH, Whittaker JA. Immunolocalization and expression of the steroidogenic acute regulatory protein during the transitional stages of rat follicular differentiation. J Histochem Cytochem 1999; 47: 769-776. [Medline] [CrossRef]

52. LaVoie HA, Garmey JC, Veldhuis JD. Mechanisms of insulin-like growth factor I augmentation of follicle-stimulating hormone-induced porcine steroidogenic acute regulatory protein gene promoter activity in granulosa cells. Endocrinology 1999; 140: 146-153. [Medline]

53. Bao B, Calder MD, Xie S, Smith MF, Salfen BE, Youngquist RS, Garverick HA. Expression of steroidogenic acute regulatory protein messenger ribonucleic acid is limited to theca of healthy bovine follicles collected during recruitment, selection, and dominance of follicles of the first follicular wave. Biol Reprod 1998; 59: 953-959. [Medline] [CrossRef]

54. Pescador N, Soumano K, Stocco DM, Price CA, Murphy BD. Steroidogenic acute regulatory protein in bovine corpora lutea. Biol Reprod 1996; 55: 485-491. [Medline] [CrossRef]

55. Kerban A, Boerboom D, Sirois J. Human chorionic gonadotropin induces an inverse regulation of steroidogenic acute regulatory protein messenger ribonucleic acid in theca interna and granulosa cells of equine preovulatory follicles. Endocrinology 1999; 140: 667-674. [Medline]

56. Conley AJ, Kaminski MA, Dubowsky SA, Jablonka-Shariff A, Redmer DA, Reynolds LP. Immunohistochemical localization of 3 beta-hydroxysteroid dehydrogenase and P450 $17 \alpha$-hydroxylase during follicular and luteal development in pigs, sheep, and cows. Biol Reprod 1995; 52: 1081-1094. [Medline] [CrossRef]

57. Nishimura R, Sakumoto R, Tatsukawa Y, Acosta TJ, Okuda K. Oxygen concentration is an important factor for modulating progesterone synthesis in bovine corpus luteum. Endocrinology 2006; 147: 4273-4280. [Medline] [CrossRef]

58. Nishimura R, Komiyama J, Tasaki Y, Acosta TJ, Okuda K. Hypoxia promotes lutea cell death in bovine corpus luteum. Biol Reprod 2008; 78: 529-536. [Medline] [CrossRef]

59. Kowalewski MP, Gram A, Boos A. The role of hypoxia and HIF $1 \alpha$ in the regulation of STAR-mediated steroidogenesis in granulosa cells. Mol Cell Endocrinol 2015; 401 35-44. [Medline] [CrossRef] 